\title{
Cupriavidus pauculus
}

National Cancer Institute

\section{Source}

National Cancer Institute. Cupriavidus pauculus. NCI Thesaurus. Code C86331.

A species of aerobic, Gram negative, rod and coccus shaped bacterium assigned to the phylum Proteobacteria. This species is motile non-fermentative, oxidase and catalase positive, does not reduce nitrate and is indole negative. C. pauculus is found in water and has rarely been associated with human infection but may be considered pathogenic in immunocompromised individuals. 